„Patrzeć ciemności. Ubyć":

\title{
od mikropoetyki do mikropolityki i z powrotem (o metodzie)
}

Jakub Skurtys

\section{Mikroskopia: doświadczanie widzenia}

[S]ą to jakby poprzerywane pierścienie, z których każdy może nawlec na siebie dowolny inny. Każdy pierścień albo każde plateau ma mieć swój klimat, ton, własne brzmienie.

Gilles Deleuze o kompozycji Tysiqca plateau ${ }^{1}$

Chciałbym zacząć refleksję od przypomnienia pewnej książki dla młodzieży, napisanej przed przeszło sześćdziesięcioma laty przez cenionego niegdyś popularyzatora nauki Tadeusza Unkiewicza, pierwszego redaktora „Problemów”. Mam na myśli Podróże mikrokosmiczne prof. Rembowskiego (I wyd. 1956, II wyd. 1962), króciutką historię z pogranicza nauki, fantastyki i powieści przygodowej, utrzymaną w Verne'owskim duchu, wprost powołującą się zresztą na patronat autora 20 tysięcy mil podmorskiej żeglugi. Rzecz dotyczy tytułowych „podróży mikrokosmicznych", których podejmują się profesor biologii i polski wynalazca Jan Rembowski oraz jego młodszy kompan i siostrzeniec, piętnastoletni Syga. Jako że podróże są „mikrokosmiczne", wyprawy dotyczyć muszą właśnie tego, co małe, miniaturowe, odpowiadają tym samym na co najmniej trzy wieki marzeń o zgłębieniu tajemnic mikroświata: świata na poziomie wirusów, bakterii i życia komórkowego. 
Niezwykła jest tu jednak sama technologia podróży: Rembowski konstruuje urządzenie, które nazywa „fizjoskopem”, będące odpowiednikiem wirtualnego, połączonego z organizmem mikroskopu, pozwalającego aktywnie wpatrywać się w świat komórkowy, ale również poruszać się po nim. Działanie urządzenia zostaje szczegółowo wyjaśnione czytelnikowi na pierwszych stronach, a w samej zasadzie przeplata się popularnonaukowa metoda i czysta fantastyka. Fizjoskop nie zmniejsza bowiem człowieka, jak choćby wynalazek Wayne’a Szalinskiego ze słynnego filmu Honey, I Shrunk the Kids (1989), ale przez odwrócenie odbić zmniejsza „jego widzenie":

teraz zaś wyjaśniam tylko - tłumaczy profesor młodemu asystentowi przed pierwszą podróżą - że celem moim było zmniejszyć widzenie człowieka, zmniejszyć je tak, by widział na przykład bakterię z punktu widzenia bakterii, a więc tak, jakby człowiek był sam istotą należącą do tamtego „światka”. Ale nie zadowoliłem się sytuacją obserwatora nieruchomo tkwiącego w jednym miejscu. Trzeba było jeszcze coś uczynić. Należało uzyskać swobodę ruchu².

Opracowano zatem zewnętrzny system sterowania za pomącą prototypu współczesnego joysticka oraz otulinę, która pozwala zamknąć mikroorganiczne, sztuczne oko, przejmujące od tej pory władzę nad aparatem poznawczym podróżnika. Z zewnątrz wygląda to dziwacznie: badacz, ubrany w wielki hełm, łączący go z mikroskopem, siedzi nieruchomo przy maszynie, tymczasem gdzieś tam, w mikroświecie, w magnetycznym skafandrze Elmis (skrót od elektro-mikro-skafu) podróżuje jego „trzecie oko”, wystawione na wszelkie niebezpieczeństwa kolizji, pęknięć i konfliktów z innymi organizmami.

Historia jest niebanalna i wykracza poza ramy dziecięcej opowiastki, zwłaszcza gdy pomyślimy o okulocentrycznych fantazjach nowoczesności: oko oddzielone od ciała, protetyczne, zmniejszone do rozmiaru pojedynczej komórki, podróżuje przez organiczne przestrzenie, wpatrując się w to, co na ogół skryte w mrokach, w samo Wnętrze ${ }^{3}$. Z głową schowaną w hełmach, „podróżnicy mikrokosmiczni” do złudzenia przypominają ponadto współczesnego człowieka, zanurzonego w wirtualnej rzeczywistości, z nieco przerośniętą wersją Oculus Rift na głowie (czyżby byli ponowoczesną aktualizacją figury acefalicznej?). To, co wydaje się jednak najbardziej interesujące w fizjoskopie, to nie jego zdolność do „powiększania” świata czy „pomniejszania widzenia”, ale wrażenie pełnej immersji, którą stwarza. „Widzę... widzę... widzę....” - zachwyca się na początku Syga - „Jestem w wodzie... Jakby w wodzie... Mam zupełnie uczucie, jakby mnie otaczała..."4.

Można się w takim odczuciu zatracić, i ten los spotyka oczywiście młodego bohatera, który miast słuchać ostrzeżeń profesora, decyduje się na samodzielną wyprawę w niebezpieczną mikroprzestrzeń. Mikroskopu nie można uszkodzić z zewnątrz, jest bowiem chroniony przed przypadkowymi ruchami ludzkiego ciała, ale uszkodzeniu od wewnątrz, w mikroświecie, może ulec Elmis, np. zderzając się z innymi obiektami czy organizmami. I jak to bywa w przypadku pełnej immersji, pęknięcie sztucznego oka skończyć się musi wysłaniem fałszywych

${ }^{2}$ T. Unkiewicz, Podróże mikrologiczne profesora Rembowskiego, wyd. 2, Warszawa 1962, s. 8.

${ }^{3} \mathrm{Na}$ temat tych i podobnych fantazji nowoczesności, por. T. Swoboda, Historie oka: Bataille, Leiris, Artaud,

Blanchot, Gdańsk 2010; por. też J. Momro, Widmontologie nowoczesności. Genezy, Warszawa 2014, s. 11-19.

${ }^{4}$ T. Unkiewicz, Podróże..., s. 12. 
impulsów nerwowych do mózgu, które zaburzają właściwe funkcjonowanie ludzkich organów (to dopiero fascynująca płaszczyzna dla Gilles'a Deleuze'a, który jeszcze w tym tekście wystąpi kilkakrotnie). Dlatego „podróże mikrokosmiczne” są - jak ostrzega profesor - śmiertelnie niebezpieczne. Syga nieomal przypłaca nieroztropną wyprawę śmiercią, i choć ostatecznie udaje się go uratować, na zawsze traci ostrość widzenia w jednym oku. To tylko przypadek, kara za nieusłuchanie starszych, za nieroztropność, czy może iście biblijna alegoria piętna, odpowiednik przetrąconego biodra Jakuba ( $R d z$ 32:25)?

A jednak tę niewinną, edukacyjną historyjkę z morałem rozpoczyna nie tyle groza, ile zapewnienie o niezmożonej pasji i nieustępliwości badaczy, o cenie, którą gotowi są ponieść w imię spojrzenia „w głąb”:

Jan Rembowski i młodziutki Syga nie oddaliby tej przygody za żadne skarby świata; co więcej - przygotowują się do nowych wypraw w głąb małego świata, w głąb kropli wody, aby zbadać życie i prawa owego małego kosmosu. A czynią to nieustraszenie mimo dramatycznych, a nawet tragicznych niebezpieczeństw i przeżyć, które zazdrosna o swe tajemnice natura postawiła na ich drodze

\section{Mikrologia: teoria przeoczeń}

Orfeusz potrafi wszystko, z wyjątkiem przyglądania się temu „punktowi” wprost, z wyjątkiem przyglądania się centrum nocy w samej nocy.

M. Blanchot ${ }^{6}$

W roku 2001, na przełomie nowego milenium, Aleksander Nawarecki zorganizował na Uniwersytecie Śląskim mikrologiczną konferencję, a następnie rozpoczął redagowanie serii pod wspólnym tytułem Miniatura i mikrologia literacka (trzy tomy)7 , w 2005 roku podsumował zaś książką Skala mikro $w$ badaniach literackich ${ }^{8}$. Tam też po raz pierwszy spotkałem się z tak wyraźnie postawionym zagadnieniem „mikropoetyki”.

Nie chciałbym - pisał Nawarecki w jednej z przedmów - sugerować błędnie, że badania nad literackim zjawiskiem typu „mini” i „mikro” narodziły się na Śląsku na przełomie trzeciego tysiąclecia, gdyż chodzi o tendencję żywą w humanistyce minionego półwiecza. Próbowaliśmy tylko zintegrować „mikrokrytykę” Gastona Bachelarda, „mikrolekturę” Jeana-Pierre’a Richarda, Jakobsonowską „mikroskopię” i Barthes'owską teorię punctum oraz inne jeszcze koncepcje „mikropoetyki” czy „fenomenologii mikroskopowej", spotykane na pograniczu krytyki literackiej i filozofii - w pismach Waltera Benjamina, Theodora Adorno, Jacques'a Derridy, Jean-François Lyotarda ${ }^{9}$.

5 Tamże, s. 3

${ }^{6}$ M. Blanchot, Spojrzenie Orfeusza, przeł. M.P. Markowski, „Literatura na Świecie” 1996, nr 10, s. 36.

${ }^{7}$ Miniatura i mikrologia literacka, red. A. Nawarecki, t. 1, 2000, t. 2, 2001, t. 3, 2003 - w kolejnych przypisach opisuję skrótem MiM, z podaniem tomu.

8 Skala mikro w badaniach literackich, red. A. Nawarecki, Katowice 2005.

${ }^{9}$ A. Nawarecki, Mały Mickiewicz. Studia mikrologiczne, Katowice 2003, s. 11. 
W podobnym czasie ukazało się u nas pierwsze wydanie Mikrohistorii Ewy Domańskiej $(1999)^{10}$, „mikrologiczne” studia Przemysława Czaplińskiego (Mikrologi ze śmierciq, 2001) ${ }^{11}$ oraz Miniatura poetycka Piotra Michałowskiego (1999) ${ }^{12}$, a wszystkiemu patronowały na rodzimym gruncie Szczeliny istnienia Jolanty Brach-Czajny (1992) ${ }^{13}$, akademicko-eseistyczna refleksja nad rzeczami błahymi, drobinami, przedmiotami i czynnościami, które urastają do rangi egzystencjalnych przepaści (tytułowych szczelin).

Możemy zatem mówić o pewnego rodzaju modzie, która przypadła na przełom wieków ${ }^{14}$. Domańska diagnozowała na kartach swoich Mikrohistorii powolne odchodzenie od poststrukturalistycznego paradygmantu nauk historycznych, odsyłając czytelnika do esejów Carla Ginzburga czy Giovanniego Leviego:

\begin{abstract}
„Nowa” historia, określana przeze mnie jako „historia alternatywna”, zaproponowała inne (od tradycyjno-modernistycznego) podejścia do przeszłości i inną jej panoramę. Opowiada ona o człowieku, który został „wrzucony” w świat, o ludzkim byciu w świecie, o ludzkim doświadczaniu świata i o sposobach tego doświadczania. Jest to zatem historia doświadczeń, historia uczuć, prywatnych mikroświatów. Człowieka i jego losy poznajemy za pośrednictwem cases (przypadków), „miniatur”, antropologicznych opowieści, które jak sonda pozwalają wniknąć w codzienną rzeczywistość ${ }^{15}$.
\end{abstract}

Dwie intuicje prowadziły wówczas równocześnie Domańską w stronę perspektywy „mikro”: uwrażliwiona, egzystencjalistyczna z gruntu opowieść o „byciu w świecie” oraz antropologiczne, zapośredniczone jeszcze w tradycji Altagsgeschichte (niemiecka szkoła historii życia codziennego) eksploracje „prywatnych mikroświatów”.

W tym samym czasie w stronę antropologii refleksyjnej, podkreślającej znaczenie podmiotu badającego i jego społecznego usytuowania, kierował się Roch Sulima, swoją Antropologię codzienności (2002) również poświęcając perspektywie mikrologicznej: drobnym czynnościom, znakom przepełniającym naszą przestrzeń, przeoczeniom dnia codziennego. Zmiana przedmiotu badań pociągała za sobą zmiany w sposobie pisania: koncentrację na miniaturze, podkreślanie roli notatki i szkicu, swoiste work-in-progress, akcentujące przygodność spostrzeżeń, prywatność perspektywy i zaledwie pewną symptomatyczność wspólnego losu. Raz po raz zwracał się jednak Sulima w kierunku literatury, przywoływał Michała Głowińskiego, Mirona Białoszewskiego, wiersze „wychodzone” Juliana Przybosia, metaforyzował własną narrację, problematyzował ją pod kątem stylu i możliwości świadczenia, by osiągnąć ideał gatunkowy „małą opowieść” w analogii do „małego podboju”:

\footnotetext{
${ }^{10}$ E. Domańska, Mikrohistorie. Spotkania w międzyświatach, Poznań 2005 (cytuję za wydaniem 2, uzupełnionym i uaktualnionym, Poznań 2005).

${ }^{11}$ P. Czapliński, Mikrologi ze śmierciq. Motywy tanatyczne we wspótczesnej literaturze polskiej, Poznań 2001.

${ }^{12}$ P. Michałowski, Miniatura poetycka, Szczecin 1999.

${ }^{13} \mathrm{~J}$. Brach-Czajna, Szczeliny istnienia, Warszawa 1992.

${ }^{14}$ Więcej uwagi temu zagadnieniu, jak również potencjalnej „innowacyjności” śląskiej metody mikrologicznej, poświęciła ostatnio Ewelina Szułek: Moda na małe? Innowacyjność śląskiej mikrologii literackiej, „Postscriptum Polonistyczne" 2016, nr 1(17), s. 179-191.

${ }^{15}$ E. Domańska, Mikrohistorie..., s. 63.
} 


\begin{abstract}
Antropolog codzienności nie musi podbijać po to, jak czynił na przykład Kortez, aby raportować, czyli działać tak, jakby jedynym celem podboju było napisanie relacji [...]. Antropolog codzienności czyni „podboje małe” i raportuje o nich nie tyle Waszym Wysokościom, ile samemu sobie. [...] Raporty opowiadają świat, a nie klasyfikują go. Opowieściami tymi rządzi - gwarantująca spójność potocznego doświadczenia - logika rzeczy i zdarzeń „dla nas”, a nie logika pojęćć.
\end{abstract}

„Czarna mikrologia” Nawareckiego ${ }^{17}$, utworzona na zasadzie ukłonu w stronę „białej mitologii” Jacques'a Derridy, odsyłająca nas zarazem do problemu śmiertelności istot i kruchości rzeczy, pojawiła się zatem w ciekawym momencie rozwoju naszych nauk humanistycznych, gdzieś na pograniczu między wykorzystanym już w praktyce interpretacyjnej dekonstrukcjonizmem i powolnym wyczerpywaniem się tzw. French Theo$r y^{18}$, a jeszcze przed „zwrotem kulturowym”, przychodzącym za pośrednictwem krakowskiego patronatu Ryszarda Nycza i kręgu „KTL”19. Była wciąż jeszcze propozycją klasycznej filologii po zwrocie lingwistycznym i poststrukturalnym, z istotnymi elementami close reading, ale dostrzegała już tendencję do odchodzenia od tekstów literackich w stronę zjawisk kulturowych, od znaczenia i jego przygód ku różnym postaciom doświadczania literatury, czytelnictwa oraz osobistego zaangażowania w przedmiot.

Połowa postulatów programowych Nawareckiego brzmi więc jak hołd dla postmodernistycznych tekstualizmów, z naczelną rolą zmierzchu wielkich narracji i Derridiańskiej różni, połowa zaś jak poszukiwanie innych, pozatekstowych dróg w domenie antropologii refleksyjnej i socjologii codzienności zwłaszcza. „Mikrologię traktuję [...] jako domorosły odpowiednik czy prywatny wariant dekonstrukcji, której celem jest zakwestionowanie lub «obluzowanie» dychotomii: wielkie - małe" - stwierdza śląski badacz w Małym Mickiewiczu ${ }^{20}$, „[m]ikrologia bowiem nie chce zastąpić wielkości małością, lecz dekonstruuje tę opozycję"21.

Sama mikrologia przywoływana jest zresztą za Lyotardem, który, prześledziwszy awangardowe skłonności do minimalizmu, obarczył ją ciężarem wzniosłości i resztkową odpowiedzialnością za wypełnienie luk w wielkim, oświeceniowym projekcie rozumu. „Mikrologia - pisał francuski filozof - nie jest metafizyką w okruchach [...], wpisuje w zmierzch wielkiej myśli filozoficznej zdarzenia myśli jako niepomyślane, które pozostaje do pomyślenia"22. Mikrologia jest tu zatem nie tyle metodą, ile obowiązkiem, zadaniem do wypełnienia i wezwaniem do myślenia tego, co dotąd nie miało swojego miejsca w dyskursach nowoczesnych (sam Nawarecki stwierdza wielokrot-

\footnotetext{
${ }^{16}$ R. Sulima, Antropologia codzienności, Kraków 2000, s. 8, 9.

${ }^{17}$ A. Nawarecki, Czarna mikrologia, [w:] Skala mikro..., s. 9-24.

${ }^{18}$ Por. E. Domańska, M. Loba, Wprowadzenie, [w:] French Theory w Polsce, red. E. Domańska, M. Loba, Poznań 2010, s. 7-20.

${ }^{19}$ Pierwsze wydanie Kulturowej teorii literatury. Główne pojęcia i problemy to wszak dopiero rok 2006; sam „założycielski” tekst Nycza Kulturowa natura, słaby profesjonalizm. Kilka uwag o przedmiocie poznania literackiego i statusie dyskursu literaturoznawczego pojawił się pierwszy raz w tomie Sporne i bezsporne problemy współczesnej wiedzy o literaturze, red. W. Bolecki, R. Nycz, Warszawa 2002.

${ }^{20}$ Nawarecki, Mały Mickiewicz..., s. 11.

${ }^{21}$ Tamże, s. 14.

${ }^{22}$ F. Lyotard, Wzniosłość i awangarda, przeł. M. Bińczyk, „Teksty Drugie” 1996, nr 2/3, s. 185.
} 
nie, że na pewno nie jest to metodologia, raczej „wymiar myślenia”, „perspektywa”, „ujęcie”23).

Ta droga prowadzi przez Theodora W. Adorna i Waltera Benjamina aż do romantyków niemieckich, do Schlegla, Novalisa i Franza Schuberta. Poetyką fragmentu zaświadcza się o kruchości istnienia, umiłowaniem zbieractwa rzeczy drobnych, swoistym bibelociarstwem, składa hołd Aniołowi Historii, ocalając osadzające się okruchy, materialne ślady działalności ludzkiego ducha (taka była zresztą wymowa pierwszej „mikrologicznej” pracy Nawareckiego o wyobraźni i przedmiotach Skamandrytów ${ }^{24}$ ). Drobna zmiana perspektywy w przedmowie do ostatniego tomu „Mikrologii” z 2005 roku odsuwa jednak w cień ten wiekowy pochód autorytetów, a szkic koncentruje się, zupełnie jak u Sulimy, na samym badaczu, na trzymanej przez niego ściereczce z mikrofibry, na porządku codzienności, i każe zadać pytanie: „jaka to ściereczka?”25. To już nie jest przestrzeń namysłu nad literaturą, ale wynikłe z ciekawości uprawianie antropologii rzeczy małych, „małych opowieści”, na styku tekstów i praktyk kulturowych.

Podobne pęknięcie widać również w przywołanych przez Nawareckiego Mikrologach ze śmierciq Przemysława Czaplińskiego. Zapowiada je wszak (na tylnej stronie okładki) sfabrykowana, encyklopedyczna definicja „mikrologu”, hołdująca naukowej skrupulatności i iście oświeceniowemu obiektywizmowi, by już w kolejnych rozwinięciach uprawiać twórczą zdradę i obstawać przy „lekturze nastawionej na drobiny tekstu”, która „polega na wchodzeniu w szczeliny dzieła, na uprawianiu lekturowego krzątactwa, na ustawicznym krążeniu od opowieści wielkich do małych"26. To nie tylko propozycja metodologiczna, definiująca sposób czytania i interpretowania, który okazuje się sprzeczny z XX-wiecznymi ideałami naukowości; to pewna egalitarna i antyprzemocowa filozofia bycia i zarazem teoretyczna konceptualizacja niezobowiązujących, a jednak produktywnych poznawczo czynności, których przestrzenią pozostaje codzienność, podstawową zaś techniką pragmatyczne przyswojenie.

Jeśli przyjrzeć się tekstom pozostałych badaczy, zgromadzonych w mikrologicznych tomach Nawareckiego, motywacjom ich poszczególnych studiów lub ich nieformalnej metodologii (bo nie chodzi w tym momencie o podglebie teoretyczne i wyznawaną „szkołę” interpretowania), to sama mikrologia również jawić się nam będzie jako wewnętrznie sprzeczna. $Z$ jednej strony bowiem zauważyć możemy takie - wartościowane pozytywnie - wyróżniki, jak: precyzja i skrupulatność badawcza, uważność czytającego, wierność tekstowi i pozostawanie przy nim (wbrew filozoficznym i kulturowym skłonnościom do „użycia” tekstu ${ }^{27}$ ), wielokrotna lektura, śledzenie zmian i detali. Przoduje w tym zwłaszcza mocno analityczny Paweł Jędrzejko, przepisując Gadamerowską hermeneutykę na wariant close reading, a w „mikrologii” poszukując

\footnotetext{
${ }^{23}$ A. Nawarecki, Wstęp, MiM, t. 2, s. 9.

${ }^{24}$ Tegoż, Rzeczy i marzenia. Studia o wyobraźni poetyckiej Skamandrytów, Katowice 1993.

${ }^{25}$ Tegoż, Wstęp, MiM, t. 2, s. 22.

${ }^{26} \mathrm{P}$. Czapliński, Mikrologi ze śmiercią, s. 10.

${ }^{27} \mathrm{O}$ kulturowym przekształceniu poetyki i związanym z tym marginalizowaniu literatury ciekawie pisał ostatnio Tomasz Kunz: Poetyka w świetle kulturoznawstwa, „Forum Poetyki” 2015, nr 1.
} 
nie tylko narzędzia badania, ale również idealnego, hermeneutycznego pośrednika między przeszłością dzieła i teraźniejszością czytelnika:

obiektem zainteresowania mikrologii będą mikrostruktury dzieł literackich, które jednak nie muszą (choć mogą) być rozumiane jako systemowe elementy makrostruktury dzieła. W tym sensie mikrologia staje się terminem synonimicznym wobec mikropoetyki: jest więc dziedziną z pogranicza poetyki opisowej i historycznej, czyli narzędziem mogącym mieć zastosowanie w badaniach z zakresu poetyki immanentnej, normatywnej czy generatywnej - lub w konfrontacjach poetyk sformułowanych z poetykami immanentnymi ${ }^{28}$.

Proponując „swoistą metodologię «mrówczego oka»”29, postrzega Jędrzejko, uważny czytelnik i badacz dzieła Melville’a, mikrologię/mikropoetykę jako odpowiedź na zmęczenie poststrukturalistycznym upłynnieniem. Wedle tego stanowiska mikrologię „powołała do życia rozbieżność między bytem a dyskursem; łącząc - przez emocję - bytowość szczegółu i jego znakowość, mikrologia uprawnia interpretację bon fide, opartą na filologicznej rzetelności «uczenia się języka» dzieła i epoki”30.

$\mathrm{Na}$ tle wszystkich zgromadzonych w tomach tekstów Jędrzejko przedstawia jednak skrajne stanowisko analityczne. Na równych prawach pojawiać się będą praktyki zgoła odmienne, odnoszące się do innej konstrukcji badawczego podmiotu: krzątactwo, zbieractwo, krążenie (dryfowanie), „czepianie się” i „krótkowzroczność” (Nawarecki), emocjonalny stosunek do przedmiotu, umiłowanie drobiazgu, które prowadzi nas w stronę okruchów, drobin, strzępków i pozostałości, a wreszcie: anarchicznej resztki. Równocześnie „ja” będzie wówczas niepewne własnych możliwości poznawczych, na sposób Vattimowski „słabe”, nieskłonne do tworzenia syntez, poświęcające więcej uwagi sobie podobnym, czyli temu, co bezsilne, nieobecne lub niedostrzegalne, podważające własną racjonalność. Nawarecki zadaje to samo, tylko z pozoru retoryczne pytanie, które zadawali sobie dawniej de Saussure i Jakobson, rozmyślając nad strukturami anagramatycznymi:

Czyż ta manieryczna drobiazgowość, ślepa pedanteria, opętanie głupstwem nie jest odwieczną chorobą zawołanych badaczy literatury? Drobiazgowość jakby dziecinna albo sklerotycznie starcza jest przecież stylem lektury, tyleż dociekliwej, co niefrasobliwej, którą za wzór stawia Barthes ${ }^{31}$.

O ile pierwszej z zarysowanych tendencji patronuje wynalazek mikroskopu, na którym spoczywa wciąż obietnica poznania fundamentów rzeczywistości, a podmiotem pozostaje mikrolog - badacz drobin, realizator Jakobsonowskiej precyzji i strategii „mikroskopii”32, o tyle drugiej patronuje wyimaginowana figura mikronauty, pomniejszonego człowieka, który z Verne’owskim zapałem eksploruje nieznany i niebezpieczny świat, nawet jeśli jest tylko protetycznym okiem, jak w Podróżach mikrokosmicznych profesora Rembowskiego. Dalej będzie mnie interesować właśnie figura mikronauty, wystawionego na największe niebezpieczeń-

\footnotetext{
${ }^{28}$ P. Jędrzejko, Oscylacje literackie, czyli od Gadamera do mikrologicznej krytyki świadomości, MiM, t. 2, s. 29.

${ }^{29}$ Tamże.

${ }^{30}$ Tamże, s. 56.

${ }^{31}$ A. Nawarecki, Mikrologia, genologia, miniatura, MiM, t. 1, s. 16-17.

${ }^{32}$ Por. bardzo interesujący tekst o „mikroskopii” Jakobsona, zestawiający dwie Jakobsonowskie, odległe o pięć lat analizy wierszy Baudelaire'a: B. Mytych, Mikroskopia Romana Jakobsona, MiM, t. 2, s. 19-26.
} 
stwo, jakim staje się jego własny zmysł widzenia.

\section{Mikronautyka: wi(e)dzenie}

Skoro już wszyscy uparliśmy się oniemieć, przysłano mnie unaocznić to państwu.

Konrad Góra, Wrocław ${ }^{33}$

Tak zaczyna się poemat/oratorium Nie Konrada Góry:

1

Drzewo - ślad. Roślinny złom.

Wstyd o brak drzazgi. Jeszcze

1

Nikt nie oślepł od

odwracania wzroku $[\ldots]^{34}$.

Utwór dotyczy tyleż samego patrzenia/widzenia, stałego tematu twórczości wrocławskiego poety, co śmierci i pustki, niedającej się sprowadzić do niczego pojedynczości ofiar katastrofy kompleksu Rana Plaza w Bangladeszu (24 kwietnia 2013), będącej wynikiem błędów konstrukcyjnych i nieumiarkowanej, kapitalistycznej chęci akumulacji poprzez eksploatację zasobów: przestrzennych, materiałowych i ludzkich. Opowiadając o nieprzekładalności śmierci, o „małej śmierci” codzienności, zbliża się Góra do idei „mikrologów” Czaplińskiego:

oddzielenie góruje tu nad sumowaniem - pisał o swoich formach poznański badacz - ponieważ przedmiotem zainteresowania były jednostkowe prawdy o śmierci, prywatne mikrologie umierania. Aby odczytać wątki tych mikrologii, odnaleźć nitki konwencji i cierpienia, gramatyki i bólu, należało - poniekąd symetrycznie względem wysiłków pisarzy - powtórzyć ich słowa swoimi słowami, ponowić próbę rozerwania tkaniny języka, nieuniknioną przy wyrażaniu prawdy jednostkowej, i próbę powtórnego jej zszycia, konieczną dla wypowiedzenia prawdy w sposób zrozumiały ${ }^{35}$.

Poemat Góry jest przepastny i totalny, ale zachowuje również mikropoetycką, mikrologiczną strukturę: każdy dystych może funkcjonować samodzielnie, każdy jest pojedynczością, każdy wytwarza niedającą się przełożyć idiomatyczność i ostatecznie oddaje głos czytelnikowi. Wchodzimy w lekturę w kilka osób, w jakieś pozornej wspólnocie („bra-/cie”, „sio-/stro”), by po przeszło tysiącu stu dystychach otrzymać ostatni, niedopowiedziany, urwany być może. „Ostatnia linijka ostatniego dystychu jest przeznaczona do napisania przez odbiorcę" - informuje Góra w końcowej Próbie wyjaśnienia [N, 138], choć bardziej niż regułę pisma przywołuje ona Norwidowski oddech: miejsce na ciszę, powietrze, pustkę.

\footnotetext{
${ }^{33}$ K. Góra, Wrocław, [w:] tegoż, Requiem dla Saddama Husajna i inne wiersze dla ubogich duchem, Wrocław 2008, s. 7.

${ }^{34}$ K. Góra, Nie, Wrocław 2016, s. 9; dalej oznaczam w tekście jako N z numerem strony; w razie potrzeby pomijam też w cytatach podziały wersyfikacyjne, numerację i inne składowe zapisu oryginału, skupiając się na samej produkcji znaczeń.

${ }^{35}$ P. Czapliński, Mikrologi ze śmiercią, s. 9.
} 
Ale nie tylko to skłania, by odnieść Nie do „mikrologu” w rozumieniu Czaplińskiego i „mikrologii”, jaką proponował Nawarecki. Również wzmianki o próbach „rozerwania tkaniny języka” i ponownego jej zszywania są właściwie wzmiankami dotyczącymi technicznej strony poematu, opisują bowiem zasadę tworzenia poszczególnych konstrukcji, z silnymi przerzutniami, nawet wewnątrzwyrazowymi, z pozornym brakiem współrzędnej łączliwości elementów oraz z niemal całkowitym brakiem orzeczeń, które fundowałyby jakąś narrację. Nie są bowiem Nie opowieścią (używam w tytulaturze form zaimka liczby mnogiej „nie”, „nich”, „nimi”, tak jak życzy sobie tego autor w Próbie wyjaśnienia), ale właśnie tkaniną, gobelinem, którym rządzi powierzchniowa (po raz kolejny powraca Deleuze) logika zszywania i prucia, a więc również zatarcia i obnażenia, zasklepienia i rozwarcia (rany), milczenia i wymówienia, makrosystemu i mikroistnienia, porządku liczb i porządku idiomatycznej egzystencji, monumentu i drobiny/okruchu. Dlatego przywołuję poemat Góry właśnie w szkicu dotyczącym mikropoetyki, okrążany przez teorie i metody: Nawareckiego, Foucaulta, Deleuze'a, przywołuję go tak, jak zamyślił sobie twórca - jako oratorium, a więc zadanie do wykonania, ale też sam sposób praktykowania mikropoetyki i najbardziej interesującego mnie w niej mikrospojrzenia. Jest to zarazem, w niespecjalnie rozległym odcinku czasu, moje trzecie podejście do napisania o Nich, jakby za każdym razem oddziaływała inna, osobna cząstka, a „ekonomia resztki” od nowa wprawiała w drgania coraz bardziej mikroskopijne fragmenty.

Na wstępie opisałem historię Sygi i profesora Rembowskiego (niejako na zasadzie analogii do otwierającej Nie bajki o „myszce, naszej wiernej towarzyszce”, będącej proceduralną instrukcją radzenia sobie z traumą), poruszony ową „trwałą utratą ostrości w jednym oku”. Moją lekturę Unkiewicza konwojował bowiem fragment z Nich, który można by potraktować zapewne w świetle mistycyzmu lub poszukiwań postsekularnych, ja myślę o nim jednak w kategoriach pragnienia, mikroczynności oraz ich związków z makrofizyką władzy: „Patrzeć/ciemności. Ubyć” [N, 34].

Czuję się zatem zobowiązany zadać pytania niepostawione dotąd ani przez Nawareckiego, ani przez żaden ze zgromadzonych w „mikrologicznych” tomach tekstów: jakie niebezpieczeństwa skrywa mikrologia? Kogo może zranić, nakłuć, rozpruć? Czy rzeczywiście pozwala wejrzeć „w głąb” i jakie są tego konsekwencje? Kto jest panem, a kto ofiarą tak pojętej mikrologii? I jak ma się sam „literacki mikroskop” do panoptycznego charakteru nowoczesności lub spektakularnej ponowoczesności? Interesuje mnie więc mikrologia drażliwa i drażniąca, niebezpieczna, na planie genologicznym zaś jej mikropoetycki odpowiednik: językowy eksperyment $\mathrm{z}$ formami życia, który nazwać trzeba mimo wszystko biopolitycznym ${ }^{36}$. To zagadnienie zmusza zaś do zmierzenia się z dwoma patronatami, które tylko zdawkowo pojawiają się w redagowanych przez Nawareckiego tomach: Michela Foucaulta i Gilles'a Deleuze'a ${ }^{37}$.

\footnotetext{
${ }^{36} \mathrm{~W}$ takim choćby wariancie, jak „biopoetykę” rozumie Przemysław Czapliński w Resztkach nowoczesności, por. tegoż, Resztki nowoczesności. Dwa studia o literaturze i życiu, Kraków 2011, s. 271-294.

${ }^{37} \mathrm{Z}$ moich wyliczeń wynika, że we wszystkich trzech tomach Miniatury i mikrologii literackiej Deleuze i Foucault pojawiają się sporadycznie i to na zasadzie fałszywych przywołań, nie związanych z mikroperspektywą. W tomie pierwszym Deleuze wespół z Guattarim występuje w otwierającym szkicu Nawareckiego w pochodzie nazwisk jako [sic!] kontynuator drogi marksistowskiej i spadkobierca szkoły frankfurckiej. W tomie drugim i czwartym powraca zupełnie przypadkowo, jako reprezentant nurtu dekonstruującego myślenie opozycjami (i autor Różnicy i powtórzenia), w trzecim zaś występuje wyłącznie na marginesie, jako komentator myśli Bergsona. Nie lepiej jest z Foucaultem: w pierwszym tomie stanowi zaledwie głos wobec „śmierci autora” Barthes'a, w drugim pojawia się w cyklu wyliczeń, ale nikt nie poświęca mu osobnego szkicu, jak dzieje się to z Jakobsonem, Bachelardem czy Barthes'em, z trzeciego i czwartego tomu zaś zupełnie znika, tak jakby historyczna i dyskursywna „mikrofizyka władzy” nie była ważna dla literackiej mikrologii. Jak widać z powyższego wyliczenia, mikrologia wymaga uzupełnień, niech więc niniejszy szkic będzie taką próbą.
} 


\section{Mikrofizyka: dzielenie władzy (nad ciałem)}

Mimo antropologicznych i socjologicznych wychyleń w stronę studiów kulturowych, mikropraktyk czy tego, co Kathleen Stewart nazwała trafnie pojetyką kulturową (cultural poiesis) ${ }^{38}$, obietnica mikrologii z tomów Nawareckiego pozostaje wciąż obietnicą hermeneutyczną i tym samym egzegetyczną: kierując wzrok na to, co najmniejsze oraz przeprowadzając lekturę w sposób jak najbardziej uważny i skrupulatny, już na wstępie zakładamy możliwość strukturalnej analogii, brzemiennego w sensy przejścia od szczegółu do ogółu, od nieznaczącego detalu do całościowej syntezy, która odbywać się będzie na wyższych poziomach znaczenia lub na kolejnych etapach semiozy (podążamy więc tak czy tak śladem Mitologii Barthes'a czy Semiologii życia codziennego Eco). Nawet idea „resztki”, tego, co się wymyka, co trwa wbrew dyskursowi badacza lub poza nim, zyskuje w takiej perspektywie dowartościowanie, a rzeczywiste proporcje sił ulegają zatarciu.

Reasumując pewien etap rozważań, można zatem zaproponować trzy odrębne sposoby podejścia do literackiej „mikrologii”. W nawiązaniu do jej resztkowego charakteru i zamiłowania do poetyki fragmentu, mikrologię możemy postrzegać jako swoistą „obronę bezbronności”, dzięki której to, co z pozoru skazane na porażkę i zapomnienie, zostaje utrwalone, zachowane, odzyskuje znaczenie, tzn. nadzieję ${ }^{39}$. Kontynuuje ona wtedy mimo wszystko hermeneutyczną ideę egzegezy świętego tekstu, nawet jeśli sam tekst - jak choćby w Księdze Brunona Schulza - uznamy za gazetę, kalendarz czy pudełko zapałek.

Można też spojrzeć na mikrologię (a zatem również każdą odmianę mikropoetyki) na zasadzie poszukiwania humanistycznych uprawomocnień. W paradygmacie zdominowanym przez nauki przyrodnicze badania w skali mikro wydają się niejednokrotnie bardziej pociągające, niż te prowadzone w skali makro. Dają pewniejsze rezultaty, łudzą obietnicą bezpośredniego odniesienia do rzeczywistości, są mniej spekulatywne, a przez to mniej podatne na błąd. Jeśli jakąś znaczącą tendencją staje się postrzeganie u nas humanistyki w kategoriach laboratoryjnych ${ }^{40}$, tkwimy tu jednak raczej wciąż w epoce mikroskopu optycznego niż Wielkiego Zderzacza Hadronów.

Ale można, i wydaje się to droga najbardziej obiecująca, podążyć za Lyotardem i zaproponować mikrologię jako następstwo rozpadu wielkich narracji, efekt odczarowania XX-wiecznej gigantomachii, roszczeń Teorii ku wszechwiedzy i ostatecznym rozstrzygnięciom. Mikrologia byłaby wtedy nie tyle obietnicą lektury wnikliwszej i bardziej dokładnej (wariantem uzurpacyjnego

\footnotetext{
${ }^{38} \mathrm{~K}$. Stewart, Cultural Poiesis: The Generativity of Emergent Things, [w:] Handbook of Qualitative Research, 3rd Edition, red. N. Denzin, Y. Lincoln, Thousand Oaks, s. 1015-1030.

${ }^{39}$ Ten resztkowy błysk nadziei, iście Benjaminowskie wychylenie, dostrzec można nawet w tak melancholijnej i pesymistycznej diagnozie, jak ta z książki Sulimy: „Falowy napływ lub odpływ rzeczy rwie pasma tradycji [...]. Raporty pokazują, w perspektywie jednostkowego doświadczenia, nie tyle «jak jest», jak coś trwa, ale jak coś właśnie "przeminęło» lub "przemija». Stąd w raporty te wpisane są sekwencje «historyczności», które pomagają rozumieć może nie tyle «mijającą» właśnie teraźniejszość, ile teraźniejszość właśnie «nadchodzącą» (R. Sulima, Antropologia..., s. 9). Nawarecki poświęca tej kategorii oddzielny przypis, łączący teologię i „ekonomię resztek” (por. A. Nawarecki, Mikrologia..., MiM, t. 1, s. 21).

${ }^{40}$ Por. R. Nycz, W stronę innowacyjnej humanistyki polonistycznej: tekst jako laboratorium. Tradycje, hipotezy, propozycje, „Teksty Drugie” 2013, nr 1-2; A. Żychliński, Laboratorium antropofikcji. Dociekania filologiczne, Poznań-Warszawa 2014; Ł. Afeltowicz, Laboratoria $w$ działaniu: innowacja technologiczna $w$ świetle antropologii nauki, Warszawa 2011; tegoż, Modele, artefakty, kolektywy: praktyka badawcza w perspektywie wspótczesnych studiów nad naukq, Toruń 2012.
} 
close reading), ile właśnie przedłużeniem - w przestrzeni metodologicznej - tendencji wynikłej z kapitulacji oświeceniowego rozumu, tendencji do pisania przyczynków, fragmentów, notatników, do eksponowania praktycznego wymiaru badań oraz przesunięcia ciężaru na osobiste historie i case studies, w stronę idiomatyczności antropologii refleksyjnej.

Tutaj dopiero zaczyna się prawdziwe pole dla mikropoetyki i tego, czym mogłaby być: nie badaniem drobin tekstowych, gnom i epigramatów, nie poszukiwaniem „szczelin istnienia” w dziełach nieliterackich, w hasłach na murach, nagrobkach, reklamach i instrukcjach użytkowania ${ }^{41}$, ale specyficzną, usytuowaną i samoświadomą taktyką działania, wymierzonego w różnorakie formy władzy, innymi słowy: poetyką życia w jego politycznym wymiarze.

Jeśli szukać podstaw tego połączenia, trzeba zwrócić się oczywiście w kierunku Michela Foucaulta i jego „mikrofizyki władzy” 42 . Chcąc zbadać podstawowe źródła opresji i siły kształtujące podmiot na poziomie społecznym, musiał dokonać drobiazgowego rozbioru dawnych dyskursów i znaleźć w nich ślady przejść między praktyką a nakazem i normą. W dwójnasób więc zawiązał węzeł swojej mikroanalizy, pokazując 1) jak daleko w głąb, do bazowych przejawów życia (aż po kwestie biologiczne i biopolityczne), sięga strukturyzująca/parcelująca/ujarzmiająca moc władzy oraz 2) w jakim stopniu podstawowe działania poszczególnych podmiotów zdolne są wymykać się jej lub odkształcać ją. Po wieloletnich poszukiwaniach zaangażowania na różnych poziomach dyskursu, finalnym wyborem Foucaulta okazała się etyczno-estetyczna „troska o siebie”, rozumiana jako rodzaj estetyki egzystencji.

Sama „estetyka egzystencji”, którą zaproponował badacz jako rozwiązanie problemu odpowiedzialności „ja” za „my” (płaszczyzną odniesienia dla jednostki pozostaje tu zawsze agora), nie bardzo daje się jednak przełożyć na teorię, rozumianą jako „skrzynka z narzędziami”, w tym wypadku używanymi do „otwierania” tekstów literackich. A przecież na takie ujęcie własnych prac przystawał francuski badacz w dwugłosie z Gilles'em Deleuze'em, który zaproponował tę nośną i do dziś aktualną metaforę relacji między teorią i praktyką: „Teoria jest skrzynką z narzędziami. Nie ma nic wspólnego z tym, co stanowi jej treść (signifiant). Musi być użyteczna. Musi funkcjonować ${ }^{43}$.

Nie temu jednak zawdzięcza Foucault jedno ze swoich najważniejszych osiągnięć, ani nawet wprowadzeniu mikrologicznej perspektywy do badania stosunków władzy, ale odwróceniu kierunku oddziaływania. Jeśli spojrzymy na Historię szaleństwa lub Nadzorować i karać, dostrzeżemy, że to nie dyskurs (sądowniczy, penitencjarny, medyczny) kształtuje u podstaw

\footnotetext{
${ }^{41}$ Można by się zastanowić nad zastosowaniem mikropoetyki jako metody czytania „mikropoezji” (micropoetries), które - za The Princeton Encyclopedia of Poetry and Poetics - określamy jako przygodne, tworzone przez amatorów, pograniczne formy literackie, będące raczej rodzajem efemerycznych praktyk kulturowych niż dziełem-artefaktem, w dużej mierze uzależnionych od kontekstu społecznego i chwilowego sposobu funkcjonowania danej wspólnoty. Por. M. Damon, Postliterary America: From Bagel Shop Jazz to Micropoetries, Iowa City 2011.

${ }^{42}$ Por. B. Banasiak, Michel Foucault - Mikrofizyka władzy, „Literatura na Świecie” 1988, nr 6(203).

${ }^{43} \mathrm{~W}$ tej samej rozmowie Deleuze, w charakterystyczny dla własnego filozofowania sposób, przedstawia praktykę jako „zbiór przesunięć z jednego punktu teoretycznego do drugiego”, teoria zaś to „przesunięcie od jednej praktyki ku drugiej", na co Foucault, badacz o zgoła odmiennym temperamencie, zdaje się chętnie przystawać (M. Foucault, G. Deleuze, Intelektualiści a władza (rozmowa między Michelem Foucault a Gilles'em? Deleuze'em), przeł. S. Magala, „Miesięcznik Literacki” 1985, nr 10/11, s. 174, 175).
} 
pragnienia, ujarzmia podmioty i urządza rzeczywistość społeczną, ale serie przygodnych, chaotycznych, umiejscowionych praktyk, inwencji i oddolnych procedur, które z początku wymykają się katalogowaniu. W tym sensie mikrotechnika władzy wyprzedza ideologię i sam dyskurs, działając niezależnie i niejako samoczynnie. Serie technologicznych ucieleśnień, praktykowanych rytmicznie czynności i dzielonych w konkretny sposób przestrzeni zachowują w sobie instytucje i dopiero finalnie „stają się widoczne” dla dyskursu, którego badaniem zajmuje się Foucault.

Jeśli w ten sposób spojrzymy na osiągnięcie francuskiego filozofa, postrzegając podmiot nie jako skutek społecznej „obróbki” przez dyskursy władzy, ale jako aktywnego aktora, którego sfera popędowa, pragnienia i podstawowe impulsy zawsze wymykają się strukturyzacji, lub innymi słowy: jeśli przyjmiemy, że Foucault nie zakończył pisania na Historii szaleństwa, lecz na Trosce o siebie, to jego „estetyka egzystencji” okaże się mikropoetyką sztuczek, chwytów i wymyków, pozwalających na obronę „ja”. W tym aspekcie odczytania Foucaulta najbardziej zadłużony był Michel de Certeau, gdy formułował „poetykę codzienności”, tzn. gdy ramy socjologicznej i antropologicznej refleksji nad formami życia codziennego wyznaczył podług narzędzi z zakresu teorii języka poetyckiego.

Pozostaje się zastanowić - komentuje de Certeau - co się dzieje z innymi, nieskończenie małymi procedurami, których historia nie „wyróżniła”, a które przecież wykazują nie mniejszą i rozliczną aktywność niemieszczącą się w sieci ustanowionych technologii. Chodzi tu szczególnie o procedury, które nie mają wstępnego warunku wymaganego przez procedury, które bada Foucault, mianowicie własnego miejsca, w którym mogłaby funkcjonować panoptyczna maszyneria. Techniki owe, nie mniej funkcjonalne, lecz pozbawione zrazu tego, co stanowiło o sile innych technik, są „taktykami”, które, jak przypuszczam, dostarczały formalnej przesłanki dla zwykłych praktyk konsumpcyjnych ${ }^{44}$.

Nie jest jednak moim celem opisywać „poetykę” nieumiejscowionych czynności wywrotowych, które de Certeau nazywa „taktykami”, a do których zalicza m.in. gotowanie, czytanie, spacerowanie, różne formy przemieszczania się czy pomieszkiwania. Mam wrażenie, że od pewnego czasu, co najmniej od ukazania się pierwszego tomu Wynaleźć codzienność (2008), jest to w naszej humanistyce wiedza powszechnie znana i stosowana. Chodzi raczej o oddanie impulsu, który wywieść można od Foucaulta: podstawowego znaczenia mikroorganizacji i oddolnych działań, przeciwstawiających się makrostrukturom Instytucji. Władzy strukturalnego podziału zaczynają odpowiadać inne rodzaje łączliwości, a zdelokalizowane, pozbawione miejsca w dyskursie, wyciekające i wymykające się czynności, będące samą materią codziennego życia, przywołują deleuzejańskie pojęcie "deterytorializacji” i mają więcej wspólnego z ekonomią pragnienia, niż mogłoby się wydawać z socjologicznej lektury de Certeau.

Nie chodzi zatem o autora Wynaleźć codzienność, ani nawet o Foucaulta, ale o możliwość działania/pragnienia, która nie pozwala na ostateczne podporządkowanie, a która jest właśnie mikropoetyką: kroków, oddechów, rytmów ciał przeciwstawionych rytmom maszyn, rozcinanych i ponownie organizowanych w poemacie Góry na prawach asyndetonu. Zauważał

${ }^{44}$ M. de Certeau, Wynaleźć codzienność. Sztuki działania, przeł. K. Thiel-Jańczuk, Kraków 2008, s. 51. 
podobny ruch mikrosegmentacji Roland Barthes, gdy kazał „zobaczyć w tekście rozdzielający język asyndetonu" ${ }^{45}$, zauważa go również de Certeau, gdy pisze o poetyce chodzenia, w której „asyndeton dokonuje selekcji i rozczłonkowania przemierzonej przestrzeni; pomija połączenia, a nawet większe jej części”, „rozciąga, usuwając połączenia i następstwa (nic w miejsce czegoś)”, „odcina: przerywa ciągłość i odrealnia jej prawdopodobieństwo”, przekształca przestrzeń w „odrębne wysepki” ${ }^{\circ}$.

Jaki byłby cel takich przekształceń u Góry? Jak zmieniają one naszą percepcję? Realna przestrzeń katastrofy zdaje się z każdą chwilą kurczyć i zasklepiać, rozrasta się za to kartografia podziałów i grodzeń, które przebiegają w poprzek ciał. Ruina w sensie materialnym ustępuje temu, co nazwać możemy ruiną fantazmatyczną: obraz niepasujących do siebie fragmentów, śmietnisko resztek, zachowujące w sobie pamięć podstawowych funkcji i praktyk, dawnych podziałów i celów, wyznaczonych w obrębie kapitalistycznego reżimu produkcji. Świadczyć, zdaje się mówić Góra, to patrzeć na ten chaos bez możliwości syntezy. Działa jeszcze natręctwo agronoma, odgórny mechanizm pomiaru ${ }^{47}$, widmo prawa: „Patrzeć, // jak druzgocony młyn / pokazuje omłot: // grodzić. Wyznaczać” [N, 77], „Mierzenie okuć. / Spójny szept w // duszącej technice. / Szablon i fetysz. // Opatrzenie wejścia, // dary wydarte śnieniu" [N, 46], „Zagoiło się / niebo za niepatrzenia. // Róg, obręb (3,8 x / 2,7 kuchnia). // Obsesje norm. / - Ubierz się. // - śmiech. Objęcie / chlebem (5,4 x 2,7 // pokój), ziemniaki i / sorgo" [N 42-43]. Tym próbom kłam zadaje jednak nieprzetłumaczalność śmierci, perspektywy ciemności (klęski spojrzenia) i ziemi (przestrzennej nieskończoności), owo „Patrzeć / ciemności. Ubyć”. „Ruina nie zjawia się przed nami - pisał Jacques Derrida - nie jest ani spektaklem, ani obiektem miłości. Jest samym doświadczeniem [...] to raczej owa pamięć otwarta niczym oko bądź oczodół pozwalający zobaczyć bez żadnego pokazywania"48. Słowa te komentował Jakub Momro w odniesieniu do Étant donnés Marcela Duchampa jako przykładu „strategii rujnacji":

nie mamy już do czynienia z demonstracją czy przedstawieniem ani nawet $\mathrm{z}$ ich zniszczeniem, lecz z dialektyczną relacją między destrukcją a konstrukcją, między materią rzeczy, od której patrzący podmiot zostaje oddzielony, a linią spojrzenia bezradnie spoczywającego na tym, co zostało mu przemocą narzucone ${ }^{49}$.

Asyndeton poematu Góry odtwarza to podstawowe napięcie, ale przekształca je w formę politycznego protestu.

\footnotetext{
${ }^{45}$ R. Barthes, Przyjemność tekstu, przeł. A. Lewańska, Warszawa 1997, s. 20.

${ }^{46} \mathrm{M}$. de Certeau, Wynaleźć codzienność..., s. 102-103.

${ }^{47}$ Przypomina Giorgio Agamben w kontekście najsłynniejszego chyba literackiego mierniczego, bohatera Kafkowskiego Zamku: „Zarówno w prawie cywilnym, jak i publicznym możność rozpoznawania granic terytoriów, wyznaczania i przyznawania parceli (ager), wreszcie rozstrzygania sporów granicznych warunkowała samo wykonywanie czynności prawnych. Dlatego mierniczy, będący również finitor (tym, kto ustala i zna granice oraz rozstrzyga o nich) par excellence, zwany był także iuris auctor, «twórcą prawa», i vir perfectissimus, «mężem w najwyższym stopniu doskonałym»" (G. Agamben, K., [w:] tegoż, Nagość, przeł. K. Żaboklicki, Warszawa 2010, s. 40).

${ }^{48}$ J. Derrida, Mémories d'aveugle, Paris 1999. Cyt. za: J. Momro, Widmontologie..., s. 17.

${ }^{49}$ Tamże.
} 


\section{Mikropolityka: uwolnione molekuły}

Podczas gdy Foucault scedował siłę działania na pojedynczy podmiot, powierzając mu zadanie troski o siebie, ze świadomością partycypowania w zbiorowym mechanizmie społecznym i możliwością mikrooddziaływania na konkretne urządzenia, w podobnym czasie Deleuze zaproponował schizoanalizę jako „mikropolityczną teorię pragnienia”, świadomy, że jest ona równocześnie jedyną możliwością prawdziwie politycznego oporu wewnątrz chłonnego, ale i nieustannie przeciekającego systemu kapitalistycznego.

W obrębie maszynizmu opisał zatem podstawowy podział na sferę molarną i molekularną, wiązania molarne (stabilne, całościowe) utożsamiając z opresyjnym porządkiem Instytucji, molekularne zaś z porządkiem rewolucyjnym i twórczym (pragnienie jest tu wolne, nie jest lokowane w żadnym celowym, z góry zadanym reżimie, a zatem nie reprodukuje jego struktur i sposobów działania). Molekuła - w wielkim uproszczeniu - staje się czymś na wzór wolnego elektronu, zdolnego łączyć się z różnymi atomami nie w celu odtwarzania wzoru (pattern), lecz by dokonać generatywnych przekształceń i wciąż wymykać się lub (po deleuzejańsku) deterytorializować makropolityczne segmenty.

To prawda, że ująć przepływ i jego kwanty daje się tylko poprzez wskaźniki linii segmentów; lecz i odwrotnie - owe wskaźniki i linie mogą istnieć tylko poprzez przepływ, który je obmywa. W każdym przypadku widzimy, że linia z segmentami (makropolityka) zanurza się i przedłuża w przepływie z kwantami (mikropolityce), które nieustannie ją przekształca i pobudza jej segmenty ${ }^{50}$.

Maszyny pragnienia zorganizowane molarnie podporządkowane są zatem prawu ogólnemu, stanowią tylko elementy powielające wzór, o jasnym i precyzyjnym przeznaczeniu (są teleologiczne), którym jest reprodukcja tegoż wzorca. Maszyny molekularne działają dla siebie, a w ich działanie wpisane jest trwonienie, błąd, ruch i zerwanie. $\mathrm{Na}$ płaszczyźnie klasycznych narzędzi poetyki najbliższe były Deleuze’owi porządki kolażu i burroughsowskich wycinanek oraz surrealistycznej przypadkowości, a zatem figury jukstapozycji i elipsy. Przedstawiając w Anty-Edypie praktykę lektury jako „montaż maszyn pragnienia, schizoidalne ćwiczenie, wydobywające $z$ tekstu jego rewolucyjną moc"51, a więc odblokowujące przepływ pragnień, opowiada się oczywiście Deleuze po stronie organizacji molekularnej, ale równocześnie przeciwko wielkiej tradycji freudowskiej i lacanowskiej, które postrzegać możemy jako warianty klasycznej hermeneutyki (w znaczeniu ćwiczeń z deszyfracji, ostatecznego close reading). Zamiast poszukiwać znaczonego lub znaczącego, Deleuze wybiera „napuszczanie ich na siebie” w energetycznej, twórczej walce, będącej zintensyfikowaniem przepływu, śledzeniem przecięć i wiązań (form i substancji) oraz ich wzajemnych relacji („molekularne przepływy kwantów"), a wreszcie tworzeniem mapy poprzecznych linii oporu. Z takich przecięć i reorganizacji segmentów powstaje mikropolityczna „maszyna wojenna” 52.

${ }^{50} \mathrm{G}$. Deleuze, F. Guattari, Tysiac plateau, red. merytoryczna J. Bednarek, przedmowa M. Herer, Warszawa 2015, s. 262.

${ }^{51}$ G. Deleuze, F. Guattari, Anti-Oedipus. Capitalism and Schizophrenia, trans. R Hurley, M. Seem, H.R. Lane, preface by M. Foucault, Minnesota 1983, s. 106.

${ }^{52}$ Por. G. Deleuze, C. Parnet, Many Politics, [w:] Dialogues, trans. H. Tomlinson, B. Habberjam, New York 1987, s. 124-148. 
Mikrologia Deleuze'a leży zatem na przeciwnym biegunie względem mikroskopii Jakobsona oraz mikrologii Richarda czy nawet Bachelarda, który obrazowi, jako „cząstce elementarnej”, również przypisywał moc wyzwalającą. Nie chodzi w niej o znaczenie detalu, o dotarcie do podstawowych, strukturalnych „cegiełek” dzieła lub tekstu, ani nawet o skalę, jak w rodzimej, śląskiej mikrologii, ale o modele myślenia o pragnieniu (a tym samym działaniu): oddolny i odgórny, rewolucyjny i zniewolony, mikro- i makrofizyczny, modele zdolne połączyć poszczególne case studies z „ogólną teorią wszystkiego" (mimochodem trzeba zauważyć, że mikrologia Deleuzejańska staje się wywrotową wersją teorii systemowej). Dopiero te modele przekładają się - poprzez organiczną (molekularną) bądź techniczną (molarną) metaforykę łączliwości - na konkretne procedury, które nazwać byśmy mogli językowymi lub ściślej nawet poetologicznymi.

Trzeba jednak pamiętać, że owo myślenie o maszynach pragnienia nie jest myśleniem o rozmiarach, ale typowo merologicznym: relacji części do całości.

Rzecz w tym, że molowe i molekularne nie różni się jedynie wielością, skalą czy rozmiarem, lecz naturą danego systemu odniesień. Należy więc, być może, zastrzec słowa „linia” i „segmenty” dla organizacji molowej i szukać innych słów, które lepiej pasowałyby do składu molekularnego ${ }^{53}$.

Wiązania molarne mogą zatem scalać porządek Instytucji oraz Państwa, blokując przepływy pragnienia, podobnie jak molekularne mogą deterytorializować i tym samym uwalniać zarówno grupy, jak i poszczególne podmioty. Mikropolityka, którą proponuje Deleuze, a której idealną reprezentację znajdujemy w jego egzegezie Kopisty Bartleby'ego ${ }^{54}$, wydarza się na zasadach molekularnych: jako rysa, pęknięcie, wyznaczają ją linie przecinające i falujące, a jej duchem pozostaje zdrada, jako odmowa przynależności do większości, jako droga stawania-się-niedostrzegalnym, każdym i nikim zarazem.

Widzimy w Tysiqcu plateau, jak istotna jest dla Deleuze'a perspektywa chemii, fizyki i mikrobiologii. Łączy on paradygmaty nauki o substancjach, prawach rzeczywistości i organizmach w iście historiozoficzny traktat, jego serce bije jednak na sposób literacki (część Geologia moralności). Traktat ten jest opowieścią o szaleńczym wykładzie profesora Challengera, fikcyjnej postaci z książek Artura Conan Doyla, której towarzyszą równie literackie passusy z antropologicznej rozprawy Bóg wody Marcela Griaule, przetykane cytatami z zakresu teorii nauki oraz nauk przyrodniczych, wszystko zaś wieńczą fragmenty z H.P. Lovecrafta. Na prawach analogii zestawiają one przeprowadzoną przez Challengera dekompozycję z „mrocznym, kosmicznym rytmem” przejścia, z którego wyłania się u Lovecrafta groźna rzeczywistość. Profesor znika na koniec swojego wykładu, deterytorializuje się, przecieka poza granice porządku symbolicznego i poza granice postrzegania:

Zdezartykułowany, zdeterytorializowany Challenger mruczał, że zabiera ze sobą Ziemię, że wyrusza do tajemniczego świata, swego jadowitego ogrodu. Wyszeptał jeszcze: to przez rozprzężenie rozwijają się rzeczy i mnożą znaki. Panika jest tworzeniem. Młoda dziewczyna wrzasnęła, był to przeraźliwy krzyk „dojmującej, wszechogarniającej paniki”. Nikt nie słyszał podsumowania, nikt

${ }^{53}$ G. Deleuze, F. Guattari, Tysiac plateau, s. 260.

${ }^{54}$ Por. D. Deleuze, Bartleby czyli formuła, [w:] tegoż, Krytyka i klinika, przeł. B. Banasiak, P. Pieniążek, Łódź 2016. 
nie próbował zatrzymać Challengera. Challenger czy raczej to, co z niego zostało, spieszył wolno ku płaszczyźnie spójności, podążając po dziwnej trajektorii, gdzie nic nie było już względne ${ }^{55}$.

Chociaż opowieść udaje raz to film grozy, innym razem historie samotnika z Providence, a na kolejnym planie Nietzscheańskiego Zaratustrę, to histeryczne tezy Challengera są przecież tezami samego Deleuze'a, zaś traktat o podstawowych wiązaniach świata od poziomu mikrocząstek po prędkość i energię kosmosu, mimo wpisanego weń szaleństwa (a raczej właśnie dzięki niemu), jest schizoanalizą w praktyce. Celem wykładu (profesora i samego Deleuze’a) okazuje się tyleż przekazanie pewnej hipotezy filozoficznej, co opowiedzenie historii pękania, wycofywania się, abnegacji, która prowadzi do stawania-się-niedostrzegalnym, ostatecznej pozycji wydziedziczenia ze wszystkich molarnych schematów i włączenia się w chaotyczny przepływ wszechświa$\mathrm{ta}^{56}$. Tylko literatura może równocześnie sygnalizować sensy i pokazywać rzeczywiste działanie przyjętej przez Deleuze'a ekonomii pragnień, literatura jest bowiem praktykowaniem przepływu, ten zaś ma charakter przestrzenny. Dwie, uzupełniające się uwagi mierniczego:

Pisanie nie jest z pewnością narzucaniem formy (wyrazu) przeżytej materii. Literatura jest raczej po stronie tego, co bezforemne czy niezakończone, jak powiedział i praktykował to Gombrowicz. Pisanie jest sprawą stawania się, stawania, które wykracza poza wszelką dającą się przeżyć i przeżytą materię ${ }^{57}$.

Mówimy wyłącznie o wielościach, liniach, warstwach i segmentach, liniach ujścia i intensywnościach, układach maszynowych i ich różnych typach, ciałach bez organów i ich konstrukcji, ich doborze, płaszczyźnie spójności, jednostkach miary dla każdego z przypadków [...]. Pisanie nie ma nic wspólnego z nadawaniem znaczenia, dotyczy miernictwa, kartografii, nawet jeśli jest to kartografia okolic mających dopiero nadejść ${ }^{58}$.

Kwestia wykraczania poza materię oraz związane z pisaniem kreślenie kartografii przyszłości to oczywiście elementy „maszyny wojennej”, opartej na mikronapięciach analizy intensywności pragnienia. Wracam do idiosynkratycznego momentu: „Patrzeć/ ciemności. Ubyć” [N, 36] z pytaniem o przejście - to, które dokonuje się między dwoma czynnościami: patrzeniem i byciem oraz to, które zapowiada sam początek poematu:

\section{[...] Pójdziemy do lasu \\ w cielisty deszcz, mniejsi}

1

i wrócę sam, większy

o straconego. O nie.

$[\mathrm{N}, 9]$

\footnotetext{
${ }^{55}$ G. Deleuze, F. Guattari, Tysiac plateau, s. 86.

${ }^{56}$ Por. na temat „filozofii abnegacji” i jej politycznego wymiaru: M. Herer, Bartleby i jego bracia albo o politycznej sztuce odmowy, <http://machinamysli.org/tag/bartleby/> [dostęp: 30.01.2017]; pierwodruk: Bartleby and his brothers or the political art of refusal, „Dialouge and Universalizm” 2016, nr 2.

${ }^{57} \mathrm{G}$. Deleuze, Krytyka..., s. 5.

${ }^{58} \mathrm{G}$. Deleuze, F. Guattari, Tysiąc plateau, s. 4-5.
} 
Co zdarzyło się w lesie? Dlaczego deszcz jest „cielisty”? Jaki stosunek zachodzi między mniejszością a większością, wielością „my” a samotnością ,ja”? Jeśli ów „stracony” jest właśnie miarą tego stosunku, stawką wyprawy, to w jakim sensie jego nieobecność powiększa podmiot? Powiększa czy raczej nicuje? W jakim stopniu ten proces ma charakter „ubywania”? Czym lub kim są „one”/ „nie” z ostatniego wersu? Nie dowiemy się tego z poematu Góry, bo nie opowiada on o wycieczce z bratem i siostrą do lasu, nie jest przetworzeniem Andersenowskiej baśni, choć może się tak z początku wydawać. Raczej: on sam dzieje się w przestrzeni lasu, w rozciągłości, którą wyznacza z jednej strony materialność przerabianego drewna (sęk, drzazga, rzez), z drugiej zaś fenomenologia okaleczonej percepcji wzrokowej: „uchylenie okien od wzroku” [N, 61], „wywołany przez pomylenie wzroku negatyw” [N, 116].

Szukam zatem przejść, otwarć, mając na uwadze, że Nie to zasklepiająca się rana, że rządzi nimi „Zatarcie śladu. Sprostowanie prawdy nie o kłamstwo, o milczenie” [N, 96]. Szukam językowej materii w fazie stawania się, co kieruje mnie do przedrostków - „prze-” i „przed-”, które wytwarzają całe łańcuchy napięć. Ten pierwszy, wedle Słownika języka polskiego PWN, intensyfikuje znaczenie przymiotników oraz nadaje czasownikom nowe odcienie znaczeniowe: przestrzenne, czasowe i relacyjne. Drugi tworzy złożenia, które w zależności od kontekstu oznaczają wyprzedzanie/poprzedzanie lub opisują stosunek czynności wobec kogoś. Mamy więc cały łańcuch „leśmianizmów”, odsyłający w przeszłość, zanim jeszcze materia przybrała obecną formę: „przedrzeczy”, „przedsen”, „przedjęzyk”, „przedpamięć”. Mamy wszystko to, co sygnuje przestrzeń i poszukiwane przeze mnie momenty lub miejsca przejść: przepływ, przepadek, przełyk, przepita przeprawa, przestój, przeskok, przepaść, przebicie. Mamy intensyfikowanie znaczenia wyrazów, prowadzące do specyficznej hiperbolizacji, jakby każdy gest lub forma istnienia były w Nich przesunięte w czasie: przeoczenie, przemilczenie, przebudzenie, przełamanie, przemnożenie, przedłużenie, przeciągnięte, przerysowane, przesycone, przeznaczone, przemyślane, przeżarte, przecierające. To tylko niektóre z przykładów, i choć w lekturze ten eksplozywny charakter wymykania się - przestrzennego przesuwania lub czasowego przeciągania - działa raczej na poziomie afektów, to w powyższym zestawieniu wygląda jak zabawa słownikowa, jakby Góra odznaczał kolejne rubryki i przechodził litera po literze w karkołomnym ćwiczeniu stylistycznym.

Samo „przejście” pojawia się aż pięć razy, ale żadne z nich - czego można się spodziewać - nie jest po prostu przejściem w przestrzeni, z miejsca w miejsce, pokonaniem odległości:

Szczelina, / przejście, zaognienie [N, 47];

Sęk. Przejście do / potęgi [N, 121];

Paniczne // przejście w / stan spoczynku [N, 125];

przejściowe / gwarancje węgla [N, 72];

Odprysk, // przejście mrozu w / pieszczotę [N, 79].

To raczej „przejście” jako zmiana intensywności i znaczenia, jak w przejściu między szczeliną a zaognieniem, jak w „przejściu do potęgi” (znowu hiperbola), jak w przejściu „mrozu w pieszczotę" czy w przechodzeniu w stan spoczynku - zmienia się forma substancji, ale nie na zasadzie zmiany stanu skupienia czy przemiany jednej materii w drugą. Nie odbywa się u Góry żadna alchemia; raczej przekazywanie sobie przez słowa intensywności jak w dziecięcej grze 
w „podaj dalej”: szczelina jest przecież w pewnym sensie przejściem (szczeliny istnienia), sęk zaś dosłownie, jest przejściem zintensyfikowanym, zarośniętym śladem (w tym znaczeniu również przejściem w czasie, pomostem). Na mikropoziomie logikę Nich można by więc opisać jako logikę przejść, ale nie w znaczeniu kroków (Derridiańskiego pas), tylko przekazań, nie jako kontynuację opowieści o wyprawie do lasu, ale raczej bajkę o walce z traumą, pojętą jako blokada przepływu, koniec drogi.

\section{Mikropoetyka: powiązania}

Powszechnie wiadomo, jakie metafory-narzędzia wyciągnięto dotąd u nas z deleuzejańskiego projektu. W pierwszej kolejności skupiono się na rizomatyczności/kłączu jako strukturze narracyjnej, gramatycznej i hipertekstowej, posługiwano się kategorią nomadyczności w kontekście refleksji postkolonialnej, filozofii różnicy i problematyki inności, wykorzystano pojęcie deterytorializacji jako dywersyjnej mocy języka do wywłaszczania podmiotu ze struktur władzy. Całkiem spory nurt badań skupił się na zapożyczonej od Deleuze’a idei ciała-bez-organów, powoli w krytyce literackiej przyjmować się zaczyna również maszynizm oraz pochodna mu refleksja nad pragnieniem, zapewne dzięki niedawnemu przepracowaniu przez rodzimą humanistykę tematyki afektów.

Najciekawszym dla mikropoetyki rozwinięciem deleuzjańskiego myślenia o molarnej i molekularnej strukturze maszyn produkujących pragnienia i przeniesieniem go bezpośrednio na plan języka jest And Franco Berardiego ${ }^{59}$. Jego wcześniejszy, zainspirowany pracami niemieckich romantyków manifest na temat wyzwalającej siły poezji (The Uprising ${ }^{60}$ ), która przeciwstawia się utowarowieniu języka (counting, indexing), znalazł tu uzupełnienie w lingwistycznej teorii kultury. To właśnie mikrologiczna, molekularna zdolność języka do generatywnych przekształceń w wytwarzaniu znaczenia staje się dla Berardiego ostatnim bastionem wolnego człowieka i nieutowarowionej wspólnoty.

Kłącze nie zaczyna się i nie kończy - pisał Deleuze - jest zawsze pośrodku, pomiędzy rzeczami, między-bycie, intermezzo. Drzewo jest rodowodem, kłącze zaś to przymierze, niepowtarzalne przymierze. Drzewo narzuca czasownik „być”, tkanką łączną kłącza jest natomiast „i... i... i...”. W tej koniunkcji jest dość siły, aby wyszarpać i wykorzenić czasownik „byćc61.

Odwołując się do tego cytatu na prawach motta, Franco Berardi stworzył własną wersję mikrokrytyki semiokapitalizmu, w której język poezji umożliwia generowanie powiązań na zasadzie koniunkcji (conjunctive concatenation), a nie złączenia (connective concatenation) ${ }^{62}$. Taki język zachowuje tym samym zdolność do nieskończonej produktywności, do uwalniania pragnienia i ruchu deterytorializacji. Berardi odtwarza tym samym - na planie gramatyki, w najdrobniejszej strukturze spójników (stąd tytuł jego książki „And” - „I") - deleuzejańską opozycję

\footnotetext{
${ }^{59}$ F. Berardi, And. Phenomenology of the End: Sensibility and Connective Mutation, Cambridge, Massachusetts 2015.

${ }^{60}$ Tenże, Uprising. On Poetry and Finance, Los Angeles 2012.

${ }^{61}$ G. Deleuze, F. Guattari, Tysiac plateau, s. 29.

${ }_{62}$ “I call conjunction a concatenation of bodies and machines that can generate meaning without following a preordained design, nor obeying any inner law or finality. [...] Connection, on the other hand, is a concatenation of bodies and machines that can generate meaning only following a human-made intrinsic design, only obeying precise rules of behaviour and functioning" (F. Berardi, And...).
} 
między molarną segmentacją (connection), a molekularną produktywnością (conjunction). Tak długo, jak można dopowiedzieć kolejne słowo, a elementy w zdaniu nie odtwarzają z góry zadanego wzorca, tak długo nie będzie końca opowieści.

Biorąc sobie do serca deleuzejańską ideę kłącza jako „przymierza”, jako zasadę nieograniczonej produktywności bez początku i końca, przełożoną na struktury gramatyczne, przecinającą tekst na wspak, okalającą go i rozsadzającą, próbowałem swego czasu wyznaczyć w Nich takie właśnie, kłączowe łańcuchy czynności i odpowiadających im pól. Jednym z najdłuższych i najbardziej brzemiennych w sensy okazało się oczywiście samo „widzenie”. Od rdzenia „patrzenie” rozrastają się „opatrzenie” i „opatrzność”, „odpatrzenie”, „rozpatrzona” i „niepatrzenie”. „Oko” przechodzi w „oka”, „oczy”, „oczka”, „naoczne” oraz „przeoczenie”, „widzenie” zaś zostaje skontrowane „przewidzeniem”. Gdyby skupić się na tym jednym przepływie znaczeń, Nie byłyby uaktualnioną wersją okulocentrycznych fantazji nowoczesności, traktatem o (nie) widzeniu, jak Świetliste Andrzeja Falkiewicza czy Odwrócone światło Tymoteusza Karpowicza. Wraca do nas tym samym nurtująca mnie od początku komenda: „Patrzeć/ciemności. Ubyć”.

„Patrzeć ciemności” nie pokrywa się w żadnym razie z „widzeniem ciemności”, nie sprowadza się więc do prostej konstatacji obiektywnego stanu rzeczywistości. Sama opozycja patrzenia/ widzenia powraca od początku twórczości Góry, najbardziej wprost wyeksponowana chyba w wierszu $W$ fabryce, w którym mowa o „oku patrzenia” $\mathrm{i}$ „oku widzenia” oraz wymieniających się możliwościach obserwowania i przeżywania, świadczenia i uczestnictwa ${ }^{63}$. Jeśli weźmiemy pod uwagę, że Nie wykorzystuje i problematyzuje poetykę świadectwa, że samo jest swego rodzaju świadectwem, czy jak wolałbym to nazwać „prze-oczeniem świadectwa”, to fraza „patrzeć ciemności" uruchamia podstawową dla tomu grę napięć.

W pierwszej kolejności rozważyć trzeba wariant pozytywny, w którym wypowiedzenie to nie jest anakolutem, tylko poprawną konstrukcją składniową. Przywodzi wówczas na myśl archaiczne już użycie słowa „patrzeć” z dopełniaczem liczby pojedynczej, jak w „patrzeć zimy” (Miłosz) czy „patrzeć jutra”. Archaizacja i regionalizacja są częstymi elementami idiolektu Góry, więc i tu nie można wykluczyć takiego zabiegu. Prowadziłoby nas owo wyrażenie w kierunku „wypatrywania czegoś” w znaczeniu „oczekiwania”, a zatem - przenosząc się w przestrzeń wiersza - nadchodzących ciemności, czyli nadejścia nocy.

Załóżmy jednak, że to zdanie urwane, że „ciemność” jest w liczbie pojedynczej i zostaje spersonifikowana, że pełni funkcję dopełnienia dalszego w celowniku. Wyrażenie „patrzeć ciemności” byłoby wówczas odpowiednikiem formuły „patrzeć komuś/czemuś w oczy”, a dalej frazeologizmu „oko w oko”. Przywoływałoby zatem sytuację potencjalnie konfliktową, ale też próby porozumienia, naruszenia granicy między „ja” patrzącego i samym obiektem. Ale jeśli „ciemności” są jednak biernikiem liczby mnogiej, a nie celownikiem pojedynczej? Wtedy okazują się albo obiektem spojrzenia, albo jego modusem. Albo więc patrzymy w ciemności (a przecież o żadnych „nas”, o żadnej osobie nie ma tu mowy - jest tylko naga czynność, nakaz), wywołujemy z nich kształty, albo też - $\mathrm{i}$ ku temu rozwiązaniu byłbym bardziej skłonny - przy-

${ }^{63}$ „Teraz to widzę okiem widzenia / Teraz tam patrzę okiem patrzenia” - od tych wersów zaczyna się wiersz Góry (K. Góra, W fabryce, [w:] Requiem..., s. 60). 
wołujemy same ciemności. Proces patrzenia jawi się już nie jako proces poznawczy w sensie oświeceniowej filozofii, z obietnicą wyjścia z platońskiej jaskini, ale twórczy (pojetyczny), nie jako wpatrywanie się w ciemność ani nawet sytuacja egzystencjalna (patrzenie w ciemnościach, niemożność poznawcza), ale jako wytwarzanie ciemności za pomocą władzy wzroku. Tak jakby to sam wzrok wywoływał ciemność w obiekcie, jakby przynależnym mu sposobem istnienia była właśnie „praca ciemności”.

Nie tylko mowa jest więc ciemna i nie tylko "przeoczenie”, powracające w Nich z siłą sądowego oskarżenia, powoduje zanikanie źródłowego obiektu. Podstawowa elipsa, eliminująca przyimek między „ciemnością” a „widzeniem”, usuwa wszelkie wskazówki ich wzajemnej łączliwości, wystawiając czytelnika na ciemną grę przeoczeń. Twierdzę jednak, że to nie przeoczenie jest najważniejszą intensywnością, wygrywaną w poemacie Góry, ale właśnie połączenie, ujęte tak, jak rozumie je Berardi - jako koniunkcja, i tak, jak rozumie je w kłączu Deleuze - jako „przymierze”. Wszak „1” z oznaczeń dystychów nie sygnują kolejności ani następstwa, nie wprowadzają podziału w sensie władzy, ani nawet nie sumują się w rzeczywistą liczbę ofiar katastrofy, jak głosiły wstępne założenia Góry (nie dość, że sama liczba ofiar nie jest pewna, to nie wiemy tak naprawdę, na którym dystychu ostatecznie poprzestaje poeta); są właśnie rodzajem „przymierza", połączenia stworzonego na zasadzie koniunkcji, odpowiadającego molekularnej wielości. Radykalne rozdzielenie z początku poematu, przerzutnia na wołaczach „sio-/stro" i „bra-/cie”, nie jest rozdzieleniem ostatecznym: jest zaledwie świadomością podziałów i segmentacji, wpisanych w każdy podmiot, rodzajem pęknięcia. Kolejny krok trzeba by więc wykonać poza siebie.

Logika „mikrologu” przypomina o konieczności rozdarcia i ponownego zszycia opowieści, poetyka somatyczna o gojeniu się i rozdrapywaniu rany, analiza przestrzenna o parcelowaniu i łączeniu wedle fantazmatycznego działania asyndetonu, analiza syntaktyczna o nieredukowalnej wielości i redukcji poprzez sumę, o samotności i braterstwie. Ostatni łańcuch prowadzi do nas „bycia” jako wyzbywania się: „Być młodszym od ognia” [N, 9], „Podjąć resztę, być okłamywanym” [N, 12] „Bić, być bitym do soku” [N, 26], wreszcie: „Patrzeć ciemności. Ubyć” [N, 36]. „U-bywanie jest operacją, którą bycie przeprowadza na otwartym sercu” ${ }^{4}$ - pisał poetycko Tadeusz Sławek, komentując stworzoną przez siebie kategorię na potrzeby rozprawy o twórczości Williama Blake’a:

jedynym punktem, który pozostaje wciąż wrażliwy na logikę „ja” i tego, co „moje”, jedynym „miejscem", które pozostało po wycofywaniu się iluzji mojego panowania nad rzeczywistością, jest cierpienie. Ból (wszelkiego rodzaju) nie może należeć do nikogo innego; pozornie chłodne, matematycznie precyzyjne i obojętne maszyny tekstowe artysty wykrzykują do nas tę porażającą prawdę: wyrzekłszy się roli władcy rzeczywistości, udzieliwszy mowie należnej jej łaski niezależności, trwam w cierpieniu, które zostaje otwarte kluczem myśli, iż jestem „mniej” - i równie dobrze „mniej” jestem - właściwie tylko „bywam”, „u-bywam”65.

U Góry nie mamy lekkości tego zaproszenia, lecz nakaz: ubyć, usunąć „ja” z poetyki świadectwa, ubywać w „patrzenie ciemności”, wyciekać poza władze wzroku, jak profesor

${ }^{64}$ T. Sławek, U-bywać. Człowiek, świat i przyjaźń w twórczości Williama Blake’a, Katowice 2001, s. 252.

${ }^{65}$ Tamże, s. 251-252. 
Challenger; narazić się na cierpienie, okaleczenie, trwałą ślepotę, jak Syga. Jak głosi legenda, eksperyment formalny Nie rozwijał się wszak w ciemności, z nasłuchu niewidocznych mikrozdarzeń. Opowiadał poeta w jednym z wywiadów o metodzie, jaką przyjął na potrzeby pisania:

Konrad Góra: Wziąłem od Blake’a jego technikę poetycką, którą jakoś można pożenić z wyzbywaniem się siebie i jednocześnie niemnożeniem bytów nad konieczność [...] najwyraźniejszą przygodę $\mathrm{z}$ tą metodą miałem w Poznaniu, gdzie dostałem pracownię w piwnicach od:Zysku, siedziałem tam najgłębiej, jak się da, w połowie rynku już, w ciemności, i jedyne, co tam się mogło zdarzyć - prócz tego, że podsłuchiwałem chodzących nade mną ludzi i uważałem za wydarzenia np. to, że ktoś zamilkł, bo to jest wydarzenie, w końcu ludzie ciągle mówią - to był szczur, rudawy, nazwałem go Kajzer, i on co jakiś czas do mnie wychodził, wreszcie to się skończyło trwałą więzią, znosiłem mu pieczywo i miętowe cukierki [...]. Myślałem, że wypłoszyłem go przed rozwiązaniem od:Zysku, bo wiedziałem, że wejdą tam z deratyzacją, ale przedwczoraj mi Łojek z tamtej załogi powiedział, że zabił go Jezus, jeden z tamtejszych psów.

Dawid Mateusz: Czyli jest to dosyć czasochłonna metoda i nie obywa się bez ofiar.

Konrad Góra: Otwiera na więcej, niż zamyka ${ }^{66}$.

Ten, kto wpatruje się za długo w słońce, w końcu od niego oślepnie, ale co z tym, który wpatruje się w mroki wnętrza? Mikronauta jest trochę jak Blanchotowski Orfeusz - jak on patrzy w ślepą plamkę, w centrum nocy, i jak on nie widzi, zanurza się więc w ciemność tekstu, krąży po omacku, doświadcza własnej małości, u-bywa go.

${ }^{66} \mathrm{~K}$. Góra, D. Mateusz, Jeszcze nikt nie oślepł od odwracania wzroku, <http://www.biuroliterackie.pl/biblioteka/ wywiady/jeszcze-nikt-nie-oslepl-od-odwracania-wzroku/> [dostęp: 30.01.2017]. 


\section{SEOWA KLUCZOWE:}

KONRAD GÓRA

polska poezja po roku 2000

\section{mikrologia literacka}

\begin{abstract}
AbStrakt:
Szkic podejmuje próbę uzupełnienia „mikrologicznej" perspektywy śląskiej szkoły Aleksandra Nawareckiego o nieobecne w niej źródłowo impulsy polityczne i patronat dwóch pominiętych dotąd „mikrologów”: Michela Foucaulta i Gilles'a Deleuze'a. Opowiadając się przeciwko zdyscyplinowaniu i scjentyzmowi metody close reading, proponuje rozpatrywać badacza w kategoriach mikronauty, sam proces lektury zaś jako zanurzanie się w tekście, śledzenie drobnych napięć i przepływów znaczeń. Jest równocześnie próbą filozoficznego przeczytania poematu Nie Konrada Góry jako rozprawy o metodyce widzenia, (nie)zawinionej ślepocie i politycznej wielości.
\end{abstract}

\section{Nota o AUTORze:}

Jakub Skurtys - ur. w 1989 r., doktorant w Zakładzie Historii Literatury Polskiej po 1918 roku na Uniwersytecie Wrocławskim, krytyk. Interesuje się literaturą awangardową, poezją najnowszą oraz relacjami ekonomii i literatury. Pracuje nad rozprawą o twórczości Adama Ważyka. 